lable 1. DR, DQ and DP $\beta$ Chains trom a Panel of DRw8 B Coll Lines

\begin{tabular}{|c|c|c|c|c|c|c|c|}
\hline WS ID & Cell Name & $\mathrm{DR} / \mathrm{Dw}$ & & $\mathrm{DP}^{1}$ & $\mathrm{DR} \beta$ & $\mathrm{DQB}$ & $\overline{D P} \beta$ \\
\hline & $\mathrm{TAB}$ & & & 7 & & & \\
\hline & BTB & $w 8 / v$ & W4 & 4 & & & \\
\hline 8 & BM9 & $w 8 / v$ & w4 & $2 \mathrm{~B}$ & $\beta$ & $\beta 2$ & $\beta$ \\
\hline & MADURA & w8/w8 & $w 4$ & 4 & $\beta 1$ & $\beta 2$ & $\beta$ \\
\hline 70 & LUY & w8/8 3 & w7 & 1,4 & $\beta 1$ & $\beta 3$ & $\beta 3, \underline{\beta 5}$ \\
\hline & OLGA & w8/8 2 & w4 & $3,4^{\prime}$ & $\beta 2$ & $\beta 2$ & $\beta 2, \bar{\beta} 4$ \\
\hline 072 & SPACH & w8/8 & w4 & $4 \mathrm{~B}^{?}$ & $\beta 2$ & $\beta 2$ & $\beta 4$ \\
\hline 100 & OLL & w8/ & w4 & $34 B^{7}$ & $\beta 2$ & $\overline{\beta 2}$ & $\beta 4 \beta^{\prime}$ \\
\hline
\end{tabular}

${ }^{*} \mathrm{DQ}$ types locally determined, ${ }^{\dagger} \mathrm{DP}$ types by Eckels

( TAB", DRB1/DQB1) or DQw3 ("LUY", DR 1 1) DQ $\beta 3$ ) The "OLGA" type (DR $\beta 2 / D Q \beta 2)$ might be generated by mutations of DR $\beta 1$ into DR $\beta 2$ from "BTB" since both DR $\beta$ chains carry the DRw 8 epitope and are most likely evolutionally related

Another interesting finding is that four different DR/DQ haplotypes perfectly correlated with HLA D types, "TAB" correlated with DB7, "BTB" with Dw8, LUY" with Dw8 3, and "OLGA" with Dw8 2 In the primary MLR in one combination of these HTC cells, DR molecules dre different and may be stimulatory to each other, while in another combination DQ molecules are different and may be stımuldtory Thus, DQ molecules as well as DR molecules appear to be responsible for the HLA D specificity on the DRw8 carrying haplotype

These DR/DQ haplotypes were found differently with one or two DP molecules 1solated by B7/21 The tentative nomenclature was given to these DP molecules as previously published (2), where five distinct DP $\beta$ chdins (DPB1-DP 35 ) were described Four DP $\beta$ chains (DP $32-D P \beta 5)$ were identified (Table 1) A correlation between DP $\beta 5$ and the cellularly defined DPw4 antigen was confirmed However, the other three DP $\beta$ chains were not correlated with any DP antigens in this study

\section{References}

1 Maeda H, Hirata R, Okuyama M, Thompson A, Tohyama H Two dimensional gel analysis of a second family of class II molecules by polymorphic HLA DR4, 5, and w9 monoclonal antibodies J Immunol 1984, 1322478

2 Mdeda H, Hırata R, Jujı T, Katagırı M Isolatıon and charac terization of $9 \mathrm{C} 4$ reactive class II molecules In Aizawa M (ed) HLA in Asia Oceanı 1986 Sapporo, Hokkaido University Press, 1986, 444

\section{Author Affiliations}

Hiroo Maeda, Ranko Hirata, Blood Transfusion Service, Sattama Medical Center, Saitama Medical School, Kawagoe, Saltama, Takeo Jul, Blood Transfusion Service, Tokyo University Hospital, Tokyo, Japan

\title{
Identification of a Cellularly Defined DRW8 Subtype
}

\author{
M Bonneville, J F Moreau, M L Cheneau, F Bonneville, E Blokland, J Pool, E Goulmy,
} J D Bıgnon, JY Muller, and J P Soulıllou

Cellular mechanısms involved in the allograft rejection ptocess remain highly controversial Using monoclonal antubodies, several studies have demonstrated convinc ingly that most of the infiltrating mononuclear cells are $\mathrm{T}$ lymphocytes Moreover, several investigators have developed techniques for culturing T cells out of varrous human allografts in order to delinedte functions of intragraft $T$ cell populations

From a rejected human kidney graft a limiting dilution technique (1) was used to clone a large number of graft invading cells with clonal efficiency of $1 / 13$ Out of 55 clones, 20 were tested for 1) proliferative activity in pi imed lymphocyte cyping (PLT), 2) cytotoxic activity in cell-mediated lymipholysis (CML), and 3) cytotoxic activity inhibited by monoclonal antibodies (MAb) A large panel of well HLA-defined cells (PBL PHA-blasts, and B lymphoblastord cell lines-LCL) were used as stimulator or target cells This panel included all DRW8 positive cells from workshop homozygous B LCL (BM9, TAB 089, MADURA, BTB, OLGA, LUY, S PACHEO, OLL, SPL), seven heterozygous DRW8 positive cells from Blood Bank of Leiden (Netherlands), and cells from recipient BER (DR2 DRW6) and donor DAB (DR5-DRW8) The following MoAbs were used to inhibit cytotoxicity experiments against donor-BLCL W6 32, LEU 10, NDS 10, 1A3, B7/21, 2D6, GSP 41 NDS 13 UK 8 1, CHE 249 2, MAD 88 (all workshop redgents), and BT 29 (antı class II), D1 12 (antı DR) VI 15 (antı DR), and BM 50 (antı DR)

Clone "ID9" was selected for its ability to proliferate with and to kill only but not all cells bearing DRW8 phenotype (Table 1) This clone was significantly 
Table 1. Prohiferative and Cytotoxic Activities of Clone 1D9

\begin{tabular}{|c|c|c|c|}
\hline \multirow[b]{2}{*}{$\begin{array}{l}\text { Stımulators (PTL) } \\
\text { or Targets (CML) }\end{array}$} & \multirow[b]{2}{*}{$\begin{array}{c}\text { HLA } \\
\mathrm{DR} / \mathrm{DQ}\end{array}$} & \multicolumn{2}{|c|}{$\begin{array}{c}\text { Clone 1D9 } \\
\text { Responder/Effector }\end{array}$} \\
\hline & & $\begin{array}{l}\text { in PLT } \\
(\mathrm{cpm})^{*}\end{array}$ & $\begin{array}{l}\text { 1n CML } \\
\text { (\% lysis) }\end{array}$ \\
\hline Le \#15 (BLCL) & $7-W 8 / W 2$ & 21040 & $25 / 22$ \\
\hline $\begin{array}{l}\text { Le } \# 16(\mathrm{BLCL})^{\ddagger} \\
\text { Le } \# 24(\mathrm{PHA}\end{array}$ & $1 \mathrm{~W} 8 / \mathrm{W} 1$ & 3285 & -1 \\
\hline blasts) & W8-W13/W1 & 10383 & -1 \\
\hline $\begin{array}{l}\text { Le \#26 (PHA } \\
\text { blasts) }\end{array}$ & $1-W 8 / W 1$ & 11010 & 1 \\
\hline $\begin{array}{l}\text { Le } \# 28 \text { (PHA } \\
\text { blasts) }\end{array}$ & W8-W14/W1 & 10121 & 1 \\
\hline $\begin{array}{l}\text { Le } \# 29 \text { (PHA } \\
\text { blasts) }\end{array}$ & W8-W13/W1 & 13327 & 1 \\
\hline $\begin{array}{l}\text { Le \#31 (BLCL) } \\
\text { LUY (workshop) }\end{array}$ & $3-W 8 / W 2$ & 5055 & $-1-$ \\
\hline (BLCL) & W8/W3 & 18573 & $24 / 12$ \\
\hline $\begin{array}{l}\text { BER (reciplent } \\
\text { BLCL) }\end{array}$ & $2-W 14 / W 1$ & 2100 & 1 \\
\hline $\begin{array}{l}\text { DAB (donor } \\
\text { BLCL) }\end{array}$ & $5-W 8 / W 3$ & 20600 & $16 / 17$ \\
\hline
\end{tabular}

*Results expressed as mean (triplicate) cpm of $3 \mathrm{H}-\mathrm{TdR}$ uptake of clone cultured 72 hours with stumulating cells, ${ }^{\dagger} \%$ specific $51 \mathrm{Cr}$ release calculated at two effector/target ratios $(201 / 41)$,

$\ddagger_{\text {Leiden }} \# 16$ and $\# 31$ were not recognized by $1 \mathrm{D} 9$

inhibited by broad ant1-class II and ant1-monomorphic DR MoAb, but not by ant1-DQ or ant1-DP MoAb Monoclonal antibody MAD 88 (ant1-DRW8) elicited against DRW8 positive cell MADURA, which was lysed by clone "1D9," did not block "1D9" cytotoxicity directed against donor cell DAB (DRW8 positive) But this antibody labeled in immunofluorescence the Leiden \#16 cell (DRW8 positive), which in its turn was not lysed by "1D9" clearly suggestung that "1D9" and MoAb MAD 88 recognized two different epitopes on the $\beta$ chain of the DRW8 molecule

In order to identify at the DNA level this cellularly defined DRW8 subtype, a restriction fragment length polymorphism (RFLP) study was carried out to distinguish a DNA polymorphism of these DRW8 cells according to their sensitivity to clone "1D9" Genomic DNAs from nine DRW8 positive homozygous workshop cells, from two recognized heterozygous DRW8 positive cells (Leiden \#15 and donor DAB), and from a non-recognized heterozygous DRW8 positive cell (Leiden \#16) were digested with Eco RI, Bam HI, Taq I, and Hind III and then hybridized with workshop DR $\beta, D Q \alpha$, and
DQ $\beta$ probes With DR $\beta$ probe and all enzymes tested, DRW8 haplotype revealed a characteristic pattern distunct from those of others DR specificities Moreover a specific fragment of $89 \mathrm{~Kb}$ was noted with Taq 1 But no polymorphism was found at the DNA level because the same RFLP pattern was observed for all DRW8 positive cells including the non-recognızed Leiden $\# 16$ cell All the restriction enzyme used to hybridize the DQ $\alpha$ and $D Q \beta$ probes revealed three different $D Q$ patterns These results were concordant with those previously reported by serology (2)

In summary, clone ID9 specific for the kidney donor cells is described It killed neither K562 nor autologous BLCL On a large panel of well HLA-characterized cells it recognized a majority of DRW 8 positive cells (15/17 cells) On the other hand, all DRW8 negative cells $(\mathrm{N}=22)$ were not recognized Proliferative and cytotoxic activities were concordant RFLP analysis of DRW8 positive cells either recognized or not by 1D9 did not revealed differences with DR $\beta$ probe Hybridization with DQ $\alpha$ and DQ $\beta$ probes exhibited three different patterns without any relationship to 1D9 reactivity $1 D 9$ T-cell clone might be directed aganst a DRW8 subtype which would need further invest1gations (other restriction enzymes and probes) at the DNA level Alternatively, the DRW8 molecule might be the restriction element for some yet unknown munor alloantıgens

Acknowledgments We thank D Gauvin for her excellent technical assistance and Ms V Gallee for preparation of the manuscript

\section{References}

1 Moredu JF, Bonneville M, Peyrdt MA, Godard A, Jacques Y, Desgranges $C$ et al $T$ lymphocyte cloning from rejected human kıdney dllografts J Clin Invest 1986,78 874

2 Betuel H, Gebuhrer L, Schreuder GMT, Layrisse Z, ArnalL Villena A, Goldmann SF In Albert ED, et al (eds) Antigen report HLA DRW8 in histocompatibility testing 1984 Ber lin, Springer Verlag, p 198

\section{Author Affiliations}

$M$ Bonneville $J F$ Moreau, $J P$ Soulllou, INSERM U211 Nantes, $M L$ Cheneau $F$ Bonneville $J D$ Bignon $J Y$ Muller, Centre Transfusion, Nantes France, $E$ Blockland $J$ Pool F Goulmy, University Hospital, Leiden The Nether lands 